\title{
Epidemiological Studies on Canine Microfilariosis due to Dirofilaria repens in and around Mangalore- a Coastal Region of Karnataka
}

\author{
D. S. Malatesh*, C. Ansar Kamran, K. J. Ananda, Ganesh Udupa, \\ K. Ramesh, P. T. Suguna Rao and N. B. Shridhar \\ Department of Veterinary Medicine, Veterinary College, KVAFSU \\ Shivamogga-577 204, Karnataka, India \\ *Corresponding author
}

Keywords

Epidemiology,

Canine

microfilariosis,

D. repens,

Mangalore

Article Info

Accepted:

10 August 2019

Available Online:

10 September 2019

A B S T R A C T

A study was conducted to ascertain the epidemiology of canine microfilariosis in and around Mangalore a coastal region of Karnataka for a period of one year from March-2018 to February-2019. A total of 214 blood samples were collected from dogs suspected for microfilariosis and were screened for microfilaria by modified knott's method. Among 214 samples screened, 95 samples were found positive for microfilaria with an overall prevalence of 44.39 per cent. The species of microfilaria was identified as $D$. repens based on the morphology and micrometry. Age wise prevalence was found highest in adult dogs and least in puppies. During the study, highest prevalence was observed during North-east monsoon season from October to December months $(71.42 \%)$. The breed wise prevalence showed highest in Labrador, followed by Doberman and Golden retriever dogs. The gender wise prevalence was found higher in males $(71.05 \%)$ than females. The infection was found more in dogs kept outdoor as well as near drainage area.

\section{Introduction}

Canine filariasis is caused by several species of filarid nematodes which are widely prevalent throughout the world, more specifically in the coastal region. They belong to the super family Filarioidea and family Onchocercidae. About nine filarial nematode species known to infect dogs worldwide are Acanthocheilonema reconditum, Acanthoche- ilonema dracunculoides, Brugia malayi, Brugia pahangi, Brugia ceylonensis, Brugia patei, Cercopithifilaria grassii, Dirofilaria immitis and Dirofilaria repens (Nelson, 2011). D. immitis is also known as heartworm, distributed worldwide and endemic in North, Central and South America, Africa, southern Europe and Asia. Subcutaneous dirofilariasis due to D. repens is widely distributed throughout Europe, Asia and Africa, with higher prevalence reported 
from Sri Lanka (30-60\%), Iran (60.8\%) and Italy (20.5-25\%) (Tarello, 2002).

Most common filarial species reported in India are D. immitis, D. repens, Acanthocheilonema spp. and Brugia spp. They are distributed in various parts of India, mainly Kerala, Tamil Nadu, Karnataka, Orissa, West Bengal, Bihar, Uttar Pradesh and Maharashtra (Ravindran et al., 2014). The filarial species detected in dogs from different states of India includes D. immitis from Kerala (Valsala and Bhaskaran, 1974), C. grassi from Tamil Nadu (Balasubramaniam et al., 1975), D. immitis from Himalayas (Sarkar et al., 1976), D. immitis and A. reconditum from West Bengal (Chakrabarthi and Choudhury, 1983), D. immitis and D. repens from Orissa (Patnaik, 1989), D. repens from Kerala (Radhika, 2001), D. repens and $A$. reconditum from Karnataka (Ananda and D'Souza 2007), A. reconditum, D. immitis and $D$. repens from Maharashtra and New Delhi and Microfilaria auquieri and a novel species of Acanthocheilonema from Ladakh, India (Rani et al., 2010). In general, it is believed that, $D$. immitis is mostly prevalent in north eastern India (Bortharkur et al., 2006) while $D$. repens is confined to southern parts of the country (Ananda et al., 2006 and Sabu et al., 2005).

Domestic dogs, foxes, wolves, coyotes and wild canids act as definitive hosts for $D$. immitis and the parasite also found in more than 30 species of animals, including domestic cats and wild felids, ferrets, seals, sea lions, bears and humans (Nelson, 2011). Human is the dead end host of $D$. immitis (Dissanaik et al., 2000), since worms cannot reach maturity. Dogs, cats and wild carnivores are final hosts of D. repens and it accidentally infects humans.

D. immitis and D. repens uses mosquitoes of several genera including Culex, Aedes and
Anopheles as vectors. The distribution of Dirofilaria species is not determined by the availability of the vectors but rather by the ability of microfilariae to mature into infectious larvae in the mosquito vector, as maturation is temperature dependent. India has a wide range of climatic zones, from montane (cold, wet, pine) and semi-arid regions to the wet tropics, which make it suitable for a diverse range of vectors and pathogens of medical and veterinary importance, whose transmission and geographical distribution are closely linked to regional temperature, rainfall and humidity (Patz et al., 2005).

Prevalence of canine filariasis varies from one geographical area to another mainly because of differences in climatic conditions and distribution of vector. Risk factors for canine filariasis include age, gender, season, topography and living conditions of the dogs. The adult worms of $D$. repens are commonly found in the subcutaneous tissue causes subcutaneous dirofilariasis and are considered as moderately pathogenic. Most infections caused by $D$. repens, Acanthocheilonema spp. and Brugia spp. have minimal veterinary clinical significance, however all canine filariae can infect humans and remain important from a public health prospective (Irwin and Jefferies, 2004). Therefore, the present study was undertaken to ascertain the epidemiology of microfilariosis in dogs and its species identification, which is important for surveillance programme and therapeutic implications.

\section{Materials and Methods}

A total of 214 dogs presented to private clinics in Mangalore as well as dogs of nondescript breed captured by a nongovernmental organization for sterilization under birth control programme were included in the present study. The blood samples were 
collected from the dogs suspected for microfilariosis for a period of one year from March-2018 to February-2019 in ethylene diamine tetra acetic acid (EDTA) from recurrent tarsal vein for screening. The samples were examined on the same day for detection of microfilariae by modified Knott's method as per Lindsay (1965). The detailed history of dogs regarding age, sex, breed, topography and living conditions was recorded. The Identification of Microfilaria was done as per the description by Soulsby (1992) and Bowman (2014). To study the age wise prevalence, different age groups were categorised as <1 year, 1-3 years, 3-5 years and $>5$ years.

The season wise prevalence was recorded in four seasons - Summer (March, April and May), South-west Monsoon (June, July, August and September), North-east monsoon (October, December and November) and Winter (January and February). The breed and gender wise prevalence was also studied during the present study.

\section{Results and Discussion}

Out of 214 blood samples screened for a period of one year from March-2018 to February-2019, 95 samples were found positive for microfilaria by modified knott's method with a overall prevalence of $44.39 \%$. Morphologically, the microfilariae were unsheathed with blunt head and the tail was long, curved with hook like posterior end (Fig. 1 and Fig. 2). The length and width of microfilaria were in the range of $310.9 \pm 9.10 \mu \mathrm{m}$ and $6.51 \pm 0.14 \mu \mathrm{m}$ respectively. The morphology and morphometry indicates the microfilariae belonged to $D$. repens.

In the present study, the age wise prevalence was observed highest in $>5$ years old dogs (63.93\%) followed by 3-5 years (60\%), 1-3 years $(36.47 \%)$ and least in $<1$ year old dogs
(3.5\%). The difference in respect to age group was significant $(\mathrm{P} \leq 0.05)$. The gender wise prevalence of microfilariosis showed higher in males $(71.05 \%)$ than in females $(29.71 \%)$ and difference was statistically significant $(\mathrm{P} \leq 0.05)$.

The seasonal study revealed, highest prevalence of microfilariosis during northeast monsoon (71.42\%) followed by southwest monsoon (40.84\%), winter $(38.88 \%)$ and summer $(38.46 \%)$.

The difference between seasons was significant $(\mathrm{P} \leq 0.05) \quad$ (Table.1). A total of seven breeds of dogs were screened for microfilariosis. Out of 192 Non-descript dogs samples screened, $83(43.22 \%)$ were found positive.

Among eight Labradors, two Doberman and two Golden retriever blood samples screened, all were found positive for microfilaria whereas, four Boxer, two Great Dane and four Lhasa Apso breeds of dogs were found negative for microfilaria. The breed wise prevalence of microfilariosis was higher in Labrador, Doberman and Golden retriever breeds (Table. 2) and showed a statistically significant difference $(\mathrm{P} \leq 0.05)$.

During the study, it was also observed that, the infection was more in dogs living in both outdoor and indoor conditions (100\%), compare to dogs living exclusively in outdoor $(44.02 \%)$ and indoor conditions (20\%). The difference between living conditions was found statistically significant $(\mathrm{P} \leq 0.05)$. The topographical study revealed that, the infection was higher in dogs reared near farm topography $(100 \%)$, followed by near drainage $(44.75 \%)$, urban $(44.44 \%)$ and dogs from marshy areas were found negative for microfilaria. Statistically the difference was non-significant $(\mathrm{P} \leq 0.05)$ (Table. 3$)$. 
Fig.1 Microfilaria in modified knott's method (400X)

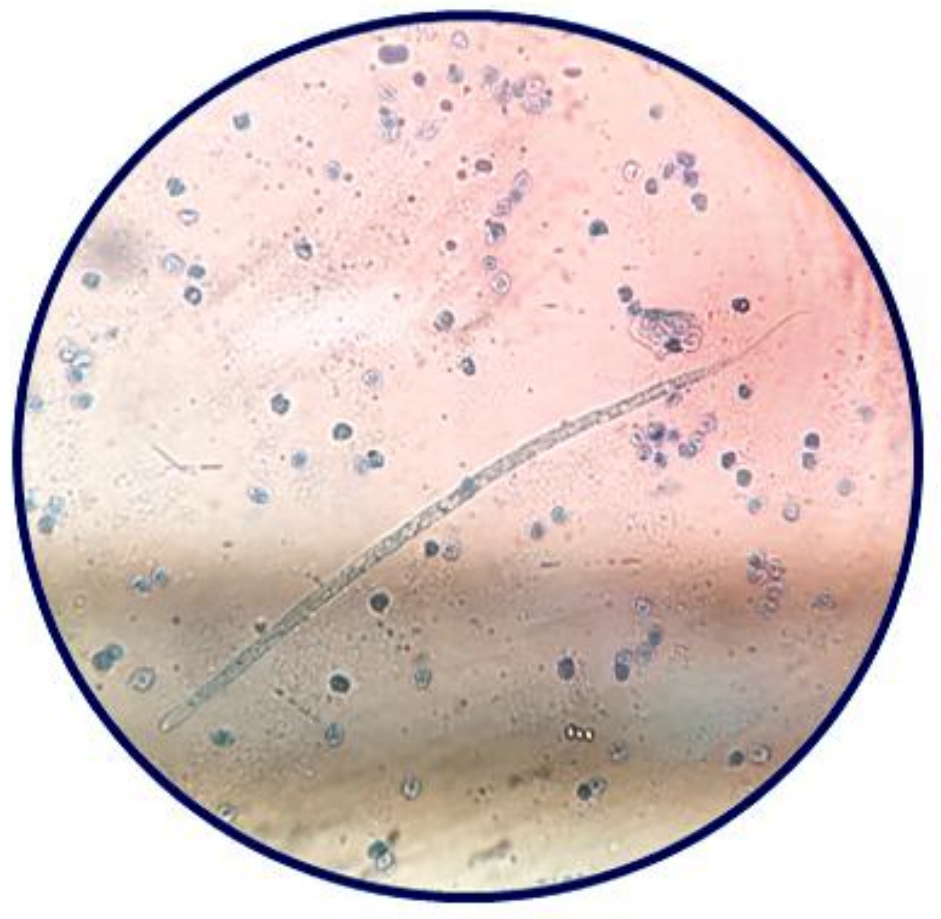

Fig.2 Microfilaria: unsheathed, (a) blunt head (b) tapering tail (400X)
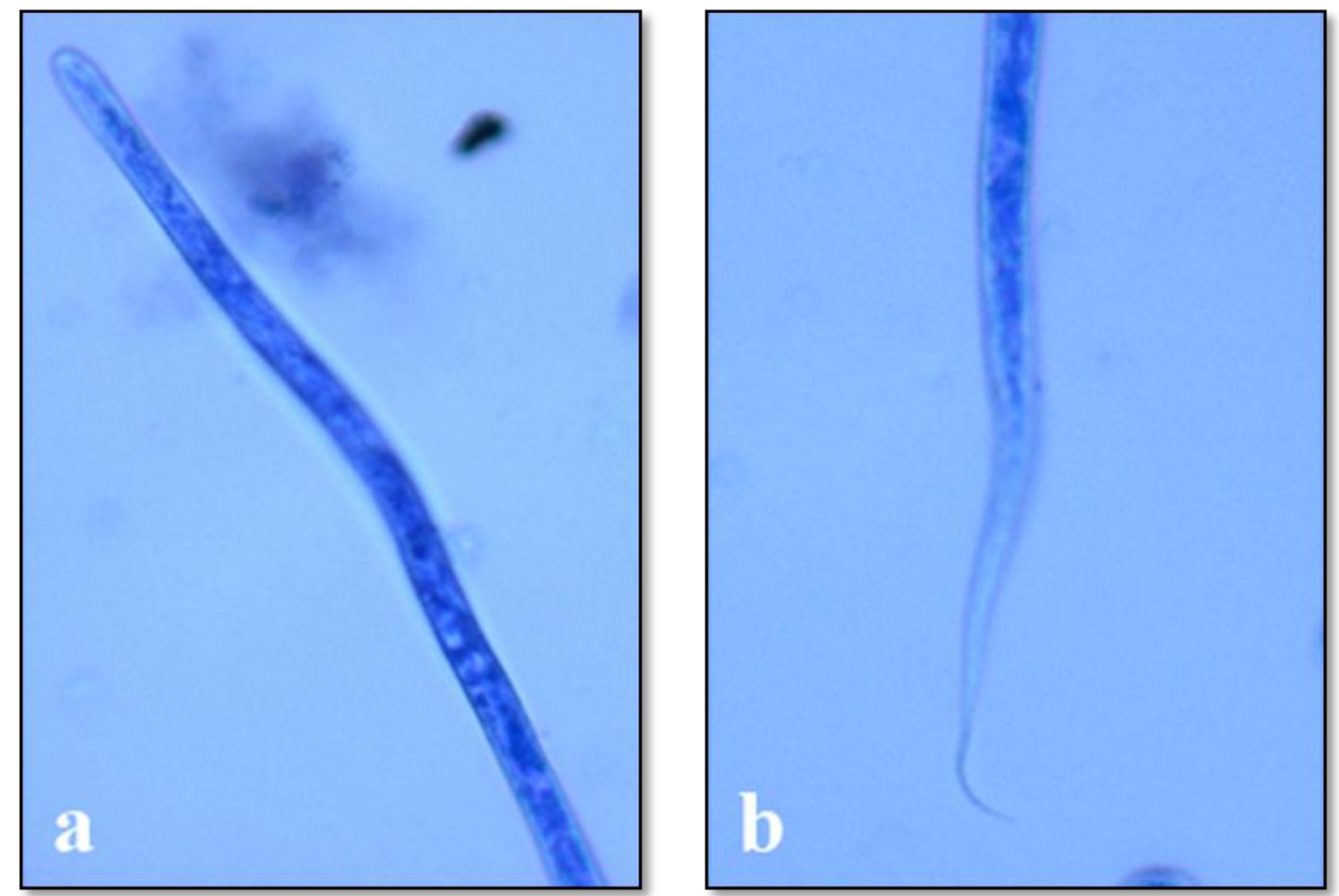
Table.1 Age wise, sex wise and season wise prevalence of microfilariosis in dogs

\begin{tabular}{|c|c|c|c|c|c|c|c|c|c|c|}
\hline & \multicolumn{4}{|c|}{ Age (Years) } & \multicolumn{2}{|c|}{ Sex } & \multicolumn{4}{|c|}{ Season } \\
\hline & $<1$ & $1-3$ & 3-5 & $>5$ & Male & Female & Summer & $\begin{array}{c}\text { South } \\
\text { West } \\
\text { monsoon }\end{array}$ & $\begin{array}{l}\text { North East } \\
\text { monsoon }\end{array}$ & Winter \\
\hline $\begin{array}{l}\text { Number of } \\
\text { dogs } \\
\text { examined }\end{array}$ & 28 & 85 & 40 & 61 & 76 & 138 & 26 & 142 & 28 & 18 \\
\hline $\begin{array}{l}\text { Number } \\
\text { positive }\end{array}$ & 1 & 31 & 24 & 39 & 54 & 41 & 10 & 58 & 20 & 7 \\
\hline $\begin{array}{l}\text { Per cent } \\
\text { Prevalence }\end{array}$ & 3.5 & $\begin{array}{c}36.4 \\
7\end{array}$ & 60 & $\begin{array}{c}63.9 \\
3\end{array}$ & 71.05 & 29.71 & 38.46 & 40.84 & 71.42 & 38.88 \\
\hline$X^{2}$ Value & \multicolumn{4}{|c|}{$34.45^{* * *}$} & \multicolumn{3}{|c|}{$33.93 * *$} & \multicolumn{3}{|c|}{$9.606^{*}$} \\
\hline
\end{tabular}

** - Significant at $\mathrm{p} \leq 0.01, *$ - Significant at $\mathrm{p} \leq 0.05$

Table.2 Breed wise prevalence of microfilariosis in dogs

\begin{tabular}{|c|c|c|c|c|c|}
\hline $\begin{array}{c}\text { Sl. } \\
\text { No. }\end{array}$ & Breed & $\begin{array}{c}\text { Number of } \\
\text { dogs } \\
\text { examined }\end{array}$ & $\begin{array}{c}\text { Number } \\
\text { positive }\end{array}$ & $\begin{array}{c}\text { Per cent } \\
\text { Prevalence }\end{array}$ & \multirow{2}{*}{ ' Value } \\
\hline $\mathbf{1 .}$ & Non-descript & 192 & 83 & 43.22 & \multirow{2}{*}{$14.63^{* *}$} \\
\hline $\mathbf{2 .}$ & Labrador & 8 & 8 & 100 & \\
\hline $\mathbf{3 .}$ & Doberman & 2 & 2 & 100 & \\
\hline $\mathbf{4 .}$ & Golden Retriever & 2 & 2 & 100 & \\
\hline $\mathbf{5 .}$ & Boxer & 4 & 0 & 0 & \\
\hline $\mathbf{6 .}$ & Great Dane & 2 & 0 & 0 & \\
\hline $\mathbf{7 .}$ & Lhasa Apso & 4 & 0 & 0 & \\
\hline
\end{tabular}

** - Significant at $\mathrm{p} \leq 0.01$

Table 3 Topography and living conditions wise prevalence of microfilariosis in dogs

\begin{tabular}{|c|c|c|c|c|c|c|}
\hline \multirow{2}{*}{} & \multicolumn{4}{|c|}{ Topography } & \multicolumn{3}{c|}{ Living conditions } \\
\cline { 2 - 7 } & $\begin{array}{c}\text { Near } \\
\text { drainage }\end{array}$ & $\begin{array}{c}\text { Near } \\
\text { farm }\end{array}$ & Urban & Both & Outdoor & Indoor \\
\hline $\begin{array}{c}\text { Number of dogs } \\
\text { examined }\end{array}$ & 181 & 6 & 27 & 10 & 184 & 20 \\
\hline $\begin{array}{c}\text { Number positive } \\
\text { Per cent } \\
\text { Prevalence }\end{array}$ & 81 & 2 & 12 & 10 & 81 & 4 \\
\hline $\mathbf{X}^{2}$ Value & 44.75 & 33.33 & 44.44 & 100 & 44.02 & 20 \\
\hline
\end{tabular}

** - Significant at $\mathrm{p} \leq 0.01, \mathrm{NS}$ : Non-significant 
During the present study, 44.39 per cent prevalence of canine microfilariosis was recorded in Mangalore region of Karnataka. Ananda and Placid (2007) reported 38.09 per cent prevalence of canine microfilariosis in Mangalore region whereas, Radhika et al., (2001) reported 7.95 per cent prevalence of canine microfilariosis in Thrissur, Kerala region. The variation in prevalence rate may be due to the fact that, the study conducted in different period of time and in different geographical area because of difference in the distribution of the vector, topography, environment and average age of the study population. Although temperature is the main influencing factor for transmission of dirofilaria as per Brown et al., (2012), many other factors influence the transmission are precipitation, relative humidity, human and animal population density and socio economic status.

The higher prevalence of microfilariosis was recorded in dogs more than 5 years old and males. This is in accordance with the previous studies (Radhika et al., 2001; Christopher and Abel-Danjuma. 2016), who reported higher rate of microfilariosis in male and older dogs. This may be due to the exploratory life style of male dogs and increased exposure risk to mosquitoes in adult dogs. The least prevalence in young puppies may be due to the fact that approximately 10 months is required for L3 larvae to become adults and then to produce microfilariae. In the present study, the higher prevalence was recorded during North-west monsoon season, while Radhika et al., (2001) reported higher prevalence in summer whereas, Deepa and Alex (2011) reported highest prevalence in winter. This variation might be due to the fact that, the mosquito vector plays role in transmission of dirofilariasis and whose development and survival need favourable climatic conditions viz. temperature, rainfall and humidity (Patz et al., 2005).
Prevalence of microfilariosis was found highest in Labrador, Doberman and Golden retriever breeds. This may be due to the representation of these breeds in this study population was highest among those examined, as reported by Bhattacharjee and Sarmah (2014).

The higher prevalence of microfilariosis was in dogs living in both outdoor and indoor conditions as well as near drainage area. This might be due to increased exposure of dogs to mosquito vector and keeping animals indoors may reduce the risk of exposure to the disease transmitting mosquitoes as reported by Walter (1996) and Theis et al., (1999).

\section{Acknowledgement}

The Authors are grateful to Department of Veterinary Medicine, Veterinary College Bangalore for providing financial assistance and Department of Veterinary Parasitology, Veterinary College, Shimoga for providing laboratory facility to conduct the present study. The authors are also thankful to Dr. Manohara Upadhaya and Dr. Yashawi Naravi for their co-operation and help during the sample collection.

\section{References}

Ananda, K.J. and Placid, E. D'souza. 2007. Prevalence of microfilariosis in dogs. Indian Vet. J., 84: 1204-1205.

Ananda, K.J., D'Souza, P.E. and Jagannath, M.S., 2006. Methods for identification of microfilaria of Dirofilaria repens and Dipetalonema reconditum. J. Vet. Parasitol., 20: 45-47.

Balasubramaniam, G., Anandan, R. and Alwar, V.S. 1975. On the occurrence of Dipetalonema grassi (Noe, 1907) from dogs in India. Indian Vet. J., 52: 513516.

Bhattacharjee K. and Sarmah, P.C. 2014. 
Epidemiological aspects of Dirofilaria immitis infection in dogs from Assam of Northeast India. Asian Pac. J. Trop. Dis., 4(1): S255-S258.

Bortharkur, S.K., Sarmah, K., Rajakhowa, T.K., Das, M.R. and Rahman, S. 2006. Dirofilaria immitis infection in a dog. J. Vet. Parasitol., 20: 167-169.

Bowman, D.D. 2014, Georgis' Parasitology for Veterinarians. 10th edition, W.B. Saunders company, Sidney., pp. 320321.

Brown, H.E., Harrington, L.C., Kaufman, P.E., McKay, T., Bowman, D.D., Nelson, C.T., Wang, D. and Lund, R. 2012. Key factors influencing canine heartworm, Dirofilaria immitis in the United States. Parasites Vectors., 30(5): 245.

Chakrabarthi A. and Choudhury, M.N. 1983. Studies on canine filariasis in West Bengal. Indian J. Anim. Health., 22: 151-155.

Christopher, I.O. and Abel-Danjuma. 2016. Prevalence and risk factors associated with Dirofilaria immitis infection in dogs in Makurdi, Benue State, Nigeria. J. Adv. Vet. Anim. Res., 3(4): 338-344.

Deepa, C. and Alex. P.C. 2011. Secondary determinants of microfilariosis in dogs-a retrospective study. J. Vet. Anim. Sci., 42: 39-41.

Dissanaik, A.S., Bandara C.D.J., Padmini H.H., Ihalmulla, R.L., Naotunne, T.D.S. 2000. Recovery of a species of Brugia, probably $B$. ceylonensis from the conjunctiva of a patient in Srilanka. Ann. Trop. Med. Parasitol., 94: 83-86.

Irwin, P.J. and Jefferies, R., 2004. Arthropodtransmitted diseases of companion animals in Southeast Asia. Trends Parasitol., 20: 27-34.

Nelson, T.C. 2011. Heartworm Disease. In: Greene, E.C. Infectious Diseases of the Dog and Cat. 4th Edn, Saunders, St Louis. pp. 865-877.
Patnaik, M.M. 1989. On filarial nematodes in domestic animals in Orissa. Indian Vet. J., 66: 573-574.

Patz, J.A., Campbell-Lendrum, D., Holloway, T. and Foley, J.A. 2005. Impact of regional climate change on human health. Nature, 438: 310-317.

Radhika, R., Subramanian, H. and Saseendranath, M.R., 2001. Prevalence of Dirofilaria repens in Thrissur. J. Vet. Anim. Sci., 32: 46-48.

Rani, M.A.P.A., Irwin, P.J., Gatne, M., Coleman, G.T., Mcinnes, L.M. and Traub, R.J. 2010. A survey of canine filarial diseases of veterinary and public health significance in India. Parasit. Vectors, 3: 30.

Ravindran, R, Varghese, S., Nair, S.N., Balan, V.M., Lakshmanan, B., Ashruf, R.M., Kumar, S.S., Gopalan, A.K., Nair, A.S., Malayil, A., Chandrasekhar, L., Juliet, S., Kopparambil, D., Ramachandran, R., Kunjupillai, R. and Kakada, S.A. 2014. Canine Filarial Infections in a Human Brugia malayi Endemic Area of India. Biomed Res Int., pp. 1-9.

Sabu, L., Devada, K. and Subramanian, H. 2005. Dirofilariosis in dogs and humans in Kerala. Indian J. Med. Res., 121(5): 691-693.

Sarkar, P., Barak, D.K. and Bhattarchajee, H.M. 1976. Pathology of Dirofilaria immitis infection in dogs. Indian Vet. J., 53: 55-57.

Soulsby, E.J.L., 1987, Helminths, Arthropods and Protozoa of Domesticated animals. Seventh Edn. ELBS Bailliere Tindal, London.

Tarello, W. 2002. Cutaneous lesions in dogs with Dirofilaria (Nochtiella) repens infestation and concurrent tick-borne transmitted diseases. Vet Dermatol., 13(5): 267-274.

Theis, J.H, Stevens, F., Theodoropoulos. G. and Ziedins, A.C., 1999. Study on the prevalence and distribution of filariasis 
in dog from Los Angeles Country, Walter, L.L., 1996. Risk factor for heartworm California (1996-1998). Canine infection in Northern California. Practice., 24: 8-16. Proceedings of the heartworm Valsala, K.V. and Bhaskaran, R. $1974 . \quad$ symposium 1995. Batavia (Ill): Dirofilariosis in dogs. Kerala J. Vet. American Heartworm Society, pp. 5-26. Sci., 5: 74-77.

\section{How to cite this article:}

Malatesh, D. S., C. Ansar Kamran, K. J. Ananda, Ganesh Udupa, K. Ramesh, P. T. Suguna Rao and Shridhar, N. B. 2019. Epidemiological Studies on Canine Microfilariosis due to Dirofilaria repens in and around Mangalore- a Coastal Region of Karnataka Int.J.Curr.Microbiol.App.Sci. 8(09): 714-721. doi: https://doi.org/10.20546/ijcmas.2019.809.086 